\title{
ONE AND ALL, ONE AND ALL EDWARD THOMPSON (1924-1993)
}

\section{Peter Linebaugh}

All we can do, and all that you would wish us to do, is to reason.

("An Open Letter to Leszek Kolakowski," 131.)

I clipped the English newspapers on 29 August 1993, the day after Edward Thompson died, partly with an eye to what would interest Edward and partly hoping to find a fitting historical context for his death. When it comes to thinking, often the best that I can do is to just select evidence. The newspapers said: university leavers have less chance than ever of finding a job, a spokesman for English Heritage opposed replacing prison windows to give inmates more air and light ("Prisons should be Prisons"), a wild elephant killed 44 people in Assam, an alliance of publishers and video producers claims to have found the identity of Jack the Ripper, the Supreme Court orders shut the factories near Taj Mahal which pollute its white marble, the London Underground says beggars are a nuisance and should be stopped, the Communists in the Philippines have begun to negotiate an end to the insurgency, Peter Rabbit is a hundred years old, Star Wars scientists deceived both Moscow and Congress, diphtheria and dysentery are epidemic in Moscow, John Monks takes over as the general secretary of the Trade union Congress (TUC), England won its first Test match in more than a year. ${ }^{1}$ It's not hard to select evidence; Thompson's life so often touched history. I'm less accustomed to reasoning, a habit that he commenced after 1956.

Although he died peacefully in his garden, his life was haunted with the idea and memory of violent death. His brother, Major Frank Thompson, was captured, tortured, interrogated, and shot on a secret mission to Bulgaria in $1944 .^{2}$ As a soldier himself, Edward risked death, and risked the death of others. After the war he became an historian and wrote history books; he became a peaceworker, and wrote about that. Looking back on his writing, it seems that violent death was one of its themes, and it's about that I'll try to reason. His writings are full of personality, of moods, of ironies, and different relationships to us, his readers; his thought and its expression were in motion. Full of passion and conviction, they also can be hard to pin down.

In surveying his writings, we may divide them between his historical studies and his political writings. Such division is clumsy, because it puts out of sight much of his poetry and his science fiction book, The Sykaos Papers (1988), and because it may cause us to overlook the process that led from one to the other and the arts common to both. Nevertheless, it is a distinction that he made. History, in "The

1 The Observer, The Independent, and The Sunday Times for 29 August 1993.

2 "The Secret State within the State," The New Statesman, 10 November 1978. With his mother Thompson edited There is a Spirit in Europe: A Memoir of Frank Thompson (1947). 
Poverty of Theory," he called his "proper work." In the Preface to Customs in Common, he mentions being "turned aside" by the peace movement.

His political writings include his articles and editing of The New Reasoner (1957-1959) which was to become The New Left Review; The Poverty of Theory (1978) containing his great essays "Outside the Whale," "The Peculiarities of the English" and the "Open Letter to Kolakowski;" Writing by Candlelight (1980) with the wickedly acerbic essays written against the secret state of the 1970s; Protest and Survive (1980) which has the revised text of the Campaign for Nuclear Disarmament (CND) pamphlet that helped inaugurate European Nuclear Disarmament (END); finally, The Heavy Dancers (1985) which has further essays from the peace movement, a personal retrospect on his war experiences, and homages to his comrades.

His history books are five. ${ }^{3}$ The biography of William Morris: Romantic to Revolutionary $(1955,1977)$ prepared the way for the revisionism of 1955 and his departure from the Communist Party in 1956. The Making of the English Working Class $(1963,1968)$ re-asserted the methodology of class analysis and established the principle of History from Below. Albion's Fatal Tree (1975), Whigs and Hunters (1975, 1977), and Customs in Common (1992) took him into the eighteenth century.

I have formed a hypothesis about these writings which can provide us with a focal point of reflection. I formulate it in extreme simplicity. It is this. In his history books violent death is presented as hanging, not as war, while in his political writings violent death appears as war, not as hanging. If true, I am not at all sure what this may mean, but I think that it bears examination. The hypothesis actually contains four suppositions, viz., that the political writings are pre-occupied with war, that the history books seldom mention war except as an external phenomenon, that hanging or capital punishment is an abiding topic in all the history books excepting William Morris, and finally, and oddly, while it is true that we may find mention, occasionally, of capital punishment in Thompson's political writings, it is mainly noticeable by its absence. Let us adduce some of the evidence for these suppositions.

First, we suppose that the political writings are concerned with war, especially, if not only, nuclear war, as we might expect from someone attempting to mobilize the peace movement. At its most intense, this writing is apocalyptic. "Exterminism, the Last Stage of Civilization" (1980), published after the secret NATO decision to deploy Cruise and Pershing missiles in Europe, anticipated the destruction of "Northern civilization and its economic and societal life-support systems." "I do not mean the extermination of all life. I mean only the extermination of our civilization," he says. He supported this view by arguing that the Cold War protagonists had developed such huge weight in the social infrastructure, not to mention the economy, to make nuclear bombs, that "the very moment of "politics" was annihilated. He suggested that exterminism is a Mode of Production. In Protest and Survive (1980) he wrote, "I have come to the view that a general nuclear war is not only possible but probable."

3 There are others, such as Family and Inheritance: Rural Society in Western Europe, 1200-1800 (Cambridge 1976), which he edited with Jack Goody and Joan Thirsk, or Unknown Mayhew: Selections from the Morning Chronicle 1849-1850 (London 1971), edited with Eileen Yeo. 
Lapsing into irony, he wrote "Such an apocalyptic expectation, which has never left me, is no doubt discreditable." His generation "had become, at a deep place in our consciousness, habituated to the expectation that the very continuation of civilization was problematic." 4 The apocalypse is imagined as the Death of All.

The apocalypse of tone and argument helped to mobilize thousands, and it provided voice to many more. He was right to say that the theme had long been with him. It is present in The New Reasoner, a journal conceived during the Hungarian Uprising of 1956 from the old Reasoner that he edited with John Saville. ${ }^{5}$ The scientist D.G. Arnot, in one of the numerous articles backing the CND, referred to "The monstrous apparatus of indiscriminate death which holds the world in fear." Mervyn Jones wrote "It's perfectly possible that everyone in Britain will be killed in nuclear war." In the summer of 1959 Thompson addressed the younger generation as "the first in the history of mankind to experience adolescence within a culture where the possibility of human annihilation has become an after-dinner platitude."

Besides the writing to the peace movement, Thompson also wrote extensively to his comrades in the Marxist tradition. Indeed he had to, insofar as the Communist Party had sought to present itself as the party of peace in the late 40 s and early 50s, his own independence was compromised unless he argued independently. From "Outside the Whale" (1960), his impassioned consideration of the weary cold war stance found in W.J. Auden and George Orwell, to "Christopher Caudwell" (1977), his tribute to the young, promethean communist killed in action on the Jarama River during the Spanish Civil War, he walked through the orthodox closures of the official version of Marxism. He came to see this as part of the intellectual moment of 1956; he compared the ideas to a geographic space, a parish whose bounds he liked to beat. He refused the Marxist theory that culture "reflects" the economy; he rejected the base/superstructure model; he parted with 'economics.'

In "The Peculiarities of the English" (1965) there is the interesting relationship between class war and war-war which was used to destroy the practicality of vigorous socialist strategy. "The movement of the 1890s crashed into the Boer War; the syndicalist surge of 1911-14 was smothered in the first great war; while the potentialities of 1945-1947 were abolished by the Cold War." ${ }^{6}$ In this essay, however, the apocalyptic urge overpowers the analysis of class struggle which, in some contexts, is seen as secondary to the saving of life: " the overthrow of imperialism has generally been, not the first item on the agenda, but a little lower down - among the other business - when we have tried to save these lives, or, perhaps, avert the annihilation of all historical agendas."

These copious essays do not adumbrate a Marxist theory of war, nor set themselves

"Notes on Exterminism, the Last Stage of Civilization" The New Left Review, 121 (May-June 1980), 26-28, and E.P. Thompson and Dan Smith, Protest and Survive (London 1980), 53.

5 John Saville, "The XXth Congress and the British Communist Party," The Socialist Register 1976, does not suggest that hanging was ever a theme in the three issues of The Reasoner.

6 The Poverty of Theory, 67. 


\section{2 left history}

alongside the writings of those who do, from Engels on through Hilferding, Luxembourg, and Lenin, to Baran and Sweezy. ${ }^{7}$ In light of these writings, it is entirely unexpected to find that Thompson's apocalypse rests on an analysis that is economic determinist. "If 'the hand-mill gives you society with the feudal lord; the steam-mill, society with the industrial capitalist,' what are we given by those Satanic mills which are now at work, grinding out the means of human extermination?' he asked the readers of The New Left Review.

Secondly, our hypothesis supposes that war is absent from Thompson's history books. In the sense that he did not write military history this is true. His conception of English history was disciplined to the traditional geography of the place whose land between the 18th and 20th century has not suffered, Thompson quotes Morris, "the ruined cornfield and the burning cottage, the mangled bodies, the untimely death of worthy men, the desolated home." 8 War, land or sea, was fought in Other Countries. The Making of the English Working Class concerns the period between 1790 and 1832, half of which time England was at war, yet these wars do not receive direct treatment. To be sure, Thompson appreciated the consequences of war upon his chosen themes: "It is as if the English nation entered a crucible in the 1790s and emerged after the Wars in a different form." 9 But it is not a book about the soldiering experiences in Haiti, or Jamaica, America, Spain, India. While soldiers and sailors walk onto the pages of the 18th century histories, it is with hat in hand as discharged veterans. The violence of the mobilization of labor in the Atlantic, the wars in the Caribbean, the conquest of America, of India, are present indirectly. In the Morris biography there is little mention of war among nations (Franco-Prussian), between states (American Civil War), or of imperialist conquest (division of Africa).

On the other hand, in Morris the class war is very much in evidence. The class war, Morris said, "lays hands on me as a recruit" and causes him to do "what in times of peace would not perhaps be lawful." The class war "is the real gate which will pull up these soft Socialists," he wrote about the Fabians. If Morris and Thompson do not linger over the question why John Burns might be in India, or Champion in Egypt, Morris was much interested in why communards were in England. His poem about them, Pilgrims of Hope, expressed the view that peace could only be "the fruit of the people's war." Virtue can arise in military defeat. "The pervasive sense of inevitable failure in the face of overwhelming odds" is how Thompson expresses part of the dilemma as it is found in Morris' Scenes from the Fall of Troy,

'God pity him' we said and God bless him,

He died well fighting in the open day' -

Yea such an one was happy I may think,

Now all has come to stabing in the dark.

Morris thought about manliness. Edward explained: if there was "sorrow and

7 Midnight Notes Collective, "Marxist Theory of War," Radical Science Journal, 14 (January 1984).

8 William Morris: Romantic to Revolutionary (1955, 1977), 389.

9 The Making of the English Working Class, 191. 
disappointment in his life, he must not indulge in the luxuries of self pity, but master them and fit himself to the work of the world in its despite." 10

Thompson shares with Morris an interest in heroes which Thompson expressed in the several homages or salutes that he offered to those he admired - Salvadore Allende, Tibor Dery, Tom Maguire, C. Wright Mills, and Tom McGrath. ${ }^{11}$ It is an unusual term. Unlike elegy, which is literary, homage is martial. Where the elegy is a song, the homage is an act. Where the elegy is mournful, the homage is reverent. The elegy is classical, the homage is feudal. The homage acknowledged superiority and allegiance; it offers service, particularly in time of war. These associations would be comfortable to Morris one of whose modes was a medievalism. There is another aspect of the homages that I would like to bring out which bears upon our suppositions: it concerns the Death of One, and contrasts, logically and historically, with the apocalypse, or the Death of All.

These deaths have a redemptive quality that Thompson brings out in his homages. William Morris was concerned with the redemptive possibility in the death of a single individual. On "Bloody Sunday," 13 November 1887, the mounted police wreaked havoc upon the thousands of Irish, Radical, and Socialist demonstrators at Trafalgar Square, killing Alfred Linnell. ${ }^{12}$ Morris composed "Death Song,"

They will not learn; they have no ears to hearken.

They turn their faces from the eyes of fate;

Their gay-lit halls shut out the skies that darken.

But, lo! this dead man knocking at the gate.

Not one, not one, nor thousands must they slay,

But one and all if they would dusk the day.

This is neither redemption, nor revenge, but revolution: "one and all" expresses solidarity at its most urgent. "All of us or none," Brecht said and Tom McGrath quoted. "We must indeed all hang together, or most assuredly we shall all hang separately," as Benjamin Franklin warned at the signing of the Declaration of Independence. An injury to one is an injury to all because co-conspirators share the same breath, because cooperation at its most elemental puts life in the hands of others. In the case of Morris" "Death Song," "one and all" is an oath, as well as a slogan. "One and All" arises in Thompson's Customs in Common. The place is Haverfordwest, the time in 1795, the action is a food riot. The curate and the magistrate are scared, we can sense the perspiration in their wringing hands, "Doctor, here are the colliers coming ... I looked up \& saw a great crowd of men women \& children with oaken bludgeons coming down the street bawling out, 'One $\&$ all - one $\&$ all'." ${ }^{13}$

Since the phrase providing our title has appeared, this is the place to digress for a moment on its meaning. Already, I think we can see that this is twofold. In Newcastle

10 E.P. Thompson, William Morris (1977), 167.

11 Most of these will be found in The Heavy Dancers (1985). "The Homage to Tom Maguire" will be found in Asa Briggs and John Saville (eds.), Essays in Labour History (London 1960).

12 Morris, 492-6.

13 Customs in Common (London 1991), 236. 


\section{4 left history}

the colliers are expressing their solidarity with the poor people of town against those who set the price of food high: "One \& all" is a slogan to be shouted while militantly marching. In Morris' "Death Song" the slogan anticipates the revolutionary "Day" when power relations among the classes are reversed. In these contexts, the expression refers to class solidarity, if not to class war. The other meaning of the phrase expresses a logical problem which had its origin in the pre-Socratic philosophers, the Problem of the One and the Many. We have adapted this to Thompson's writing: War we have considered as the Death of All, Hanging we consider as the Death of One.

Our third supposition, that hanging is an abiding topic in the history books, finds some confirmation in the Morris biography: Morris' participation in the Trafalgar Square meetings was brought about by protests against the hanging - or "judicial murder" as Thompson calls them - of the Haymarket anarchists of Chicago. "Bloody Sunday" happened the day after they were hanged, and the Socialist League helped Lucy Parsons on her English tour. Thompson's sympathies are very carefully measured in the Chicago case because in England it played an important part in the growing separation between the anarchist and labourist tendencies which corresponded between an illegal tradition of direct action and the "parliamentary" struggle which Morris supported and Thompson approves. Our third supposition finds slim support in Customs in Common which, although containing stories of two undeferential women, Anne Carter in 1629 and Hannah Smith in 1812, who were hanged for food rioting, carries little about the gallows even when it might be reasonably expected, as with the Captain Swing rioters of 1830 or the East Anglian rioters of 1816.

No, the meat of evidence for the third supposition lies in the three books: 1) The Making of the English Working Class, parts of which are rhetorically organized by descriptions of hanging, 2) Albion's Fatal Tree, whose title quotes a phrase from a Blakean euphemism for the London gallows, and 3) Whigs and Hunters, a study of a single statute, the Waltham Black Act, distinguished from all others by its innumer. able hanging offences.

The Making is in three parts, a thesis, an antithesis, and a synthesis. The theme of capital punishment appears in the first and the last, not the second part which is about the transformation of work and material life. Hanging appears in the parts of the book which are about consciousness. One is aware that they have been put there by the historian's art. Two or three substantial points about capital punishment are made as well. The first historical point he makes is that the 18 th century was a "century of Tyburn." In the 18th century, "the class war [was] fought out in terms of Tyburn." He compares Tyburn to a ritual, to a ceremony, to symbolism. He describes it as theatre. This is related to the rhetoric of The Making in which capital punishment is a drama organized by the author. ${ }^{14}$

The book virtually begins with a capital punishment that failed to come off. We read that the Privy Council is going to press a charge of high treason against Thomas Hardy. "The full penalty for a traitor was that he should be hanged by the neck, cut 
down while still alive, disembowelled (and his entrails burned before his face) and then beheaded and quartered. A Grand Jury of respectable London citizens had no stomach for this. After a nine day trial, Hardy was acquitted (on Guy Fawkes Day, 1794). The Foreman of the Jury fainted after delivering his 'Not Guilty,' while the London crowd went wild with enthusiasm and dragged Hardy in triumph through the streets." It is a sensational victory, a "moment of truth." The death of Mrs. Hardy in childbirth is secondary to this. An agon is established. Respectable citizens have defeated the Privy Council. At the same time a warning has been introduced; in the contest between the state and the individual the ending need not be so happy. We read on suspensefully knowing that the ax may fall.

It does. In the longest chapter, which virtually begins the third section of the book, "The Working Class Presence," commences: "BEHOLD THE HEAD of a traitor!" states the executioner as he holds aloft in February 1803 the decapitated head of Edward Marcus Despard. This was witnessed by Jeremiah Brandreth. Fourteen years later Brandreth had his own head held aloft in front of Derby Castle, "Behold the head of a traitor." "Between Despard and Brandreth there stretches the illegal tradition." 15

I do not mean to imply that this rhetorical selection and arrangement of texts is contrived; I point out that it is selection. Of course, the underground tradition was suppressed with hangings, and assassinations were partly an answer to it, as Thompson shows us quoting General Ludd's Triumph after frame-breaking was made a capital offense: ${ }^{16}$

The guilty may fear but no vengeance he aims

At the honest man's life or Estate

His wrath is entirely confiened to wide frames

And to those that old prices abate.

These Engines of mischief were sentenced to die

By unanimous vote of the Trade

And Ludd who can all opposition defy

Was the Grand executioner made.

Repeatedly, the struggle is summarized by executions real and pretended: the hanging of Parker after the Naval mutinies; the execution of Father O'Coigly of the United Irishmen; the inany, many burnings of Tom Paine in effigy; the hanging of Cashman in the spring of 1817 which both summarized the insurrectionary failures of the winter and in itself was a bitter provocation to the London proletariat; the Derby executions; and the hanging of the Cato Street conspirators likewise summarized particular compositions of struggle. As summary or synopsis, the Death of One epitomized political defeat.

It seems that the class war of this period, not the earlier one, is fought out in terms of the gallows - "the commercial expansion, the enclosure movement, the early years of the Industrial Revolution - all took place within the shadow of the gallows."

15 Ibid., 472 .

16 Ibid., 566. 
Hangings are "the moments of truth" when class violence is revealed. In later years Thompson will say it is generally disguised. ${ }^{17}$ In these hangings Thompson's interest is not held by the ceremonial, symbolic, ritualistic, or theatrical: he is angered by their deaths and his pity is stirred. "We may see such men as George Mellor, Jem Towle, and Jeremiah Brandreth as men of heroic stature," he writes reminding us of William Morris. George Mellor, a cropper, led the Luddites in an attack in Huddersfield. He probably assassinated the mill-owner, William Horsfall. He was hanged with two others in 1813 at York. Jem Towle, a Midlands stockinger, led an attack in Loughborough, "Luds, do your duty well. It's a Waterloo job, by God." He was hanged in November 1816, and 3000 attended his funeral in Nottingham. Brandreth, the Nottingham Luddite Captain, led the June 1817 Pentridge Uprising, "one of the first attempts in history to mount a wholly proletarian insurrection, without any middleclass support." His trial "took place in an atmosphere of terror." With William Turner, stone mason and veteran of the Egyptian campaign, and Isaac Ludlam, a Methodist and quarry owner, he was executed in Derby in November 1817.

In calling these men heroes I think that Thompson is acknowledging their redemptive powers, powers which are needed in the political present. Thus, he also wrote of Brandreth in The New Reasoner, defending him against an acid academic treatment where the curled lip of disdain insulted Brandreth again..$^{18}$ Mellor is remembered even earlier in Thompson's poem of 1950, "A Place called Choice," 19

In the frost-blue flames

Of the handloom weaver's rushlight the heroic shadows leap:

Mellor at Cartwright's mill: Jones on the hustings: names

That merge with anonymous shadows, shaping that man who crowds

Every room of the human house, opens the windows, stands

Warming the winds of space at his compassionate hands.

We think that it is not the names and shadows of Mellor and Cartwright which have shaped the man: the man's compassionate hands have dug in the archives and banged away at the typewriter to renew the causes of Mellor and Jones.

In a section on the passing of customs and the transformation of popular amusement, he raises a worrisome thought. "The passing of ... Tyburn Fair ... calls for no lament," he writes in the middle of the book. He then continues with one of those partly ambiguous judgements that one grew sensitive to noticing as apologetic of Stalinism. "However repressive and disabling the work-discipline of Methodism, the Industrial Revolution could not have taken place without some work-discipline, and, in whatever form, the conflict between old and new ways must inevitably have been painful." ${ }^{20}$ True, true. But, in context, one wonders whether it was the "Tyburn Fair," rather than the hangings, whose passing is unlamented. ${ }^{21}$ Is hanging a part of

17 Edward Thompson, "The Rule of Law in English History," Haldane Society Bulletin (Spring and Autumn, 1979).

18 E.P. Thompson, "God \& King \& Law," The New Reasoner, no.3 (Winter 1957-1958), 73-4.

19 E.P. Thompson, The Heavy Dancers (Merlin, 1985), 260.

20 The Making, 411.

21 [E.P. Thompson], "Law as Part of Culture," The Times Literary Supplement (24 April 1969) 
work-discipline, and hence inevitable? ${ }^{22}$ Is the Marxist reader or others to assume that the Industrial Revolution was an inevitable stage of history?

Hanging, thus, appears in The Making either as Tyburn Fair, which belonged to the 18th century before the English working class attained its consciousness, or it appears as the malevolent exercise of state power against selected heroes of the English working class who were forced to take desperate measures. In particular, their insurrectionary attempts are defeated, as well as their illegal tradition. What he said about Morris comes to mind: "inevitable failure in the face of overwhelming odds." The campaign against the death penalty led by Sir Samuel Romilly, which coincided with the Luddite disturbances, is not considered part of the making.

Apart from some remarks in his Preface which repeat his view about the ceremonial and cultural importance of Tyburn, Thompson, in generous deference to Doug Hay, Cal Winslow, and me (we were eager to have our say), says next to nothing about capital punishment in Albion's Fatal Tree. But I don't think that we can pass him quite by in this book, because he chose the title and the poetry at its beginning,

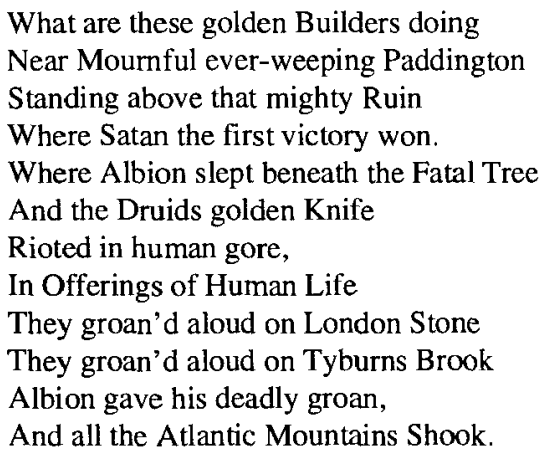

poetry which we didn't really think out. Thompson had re-printed these once before in the Blake bicentenary issue of The New Reasoner. ${ }^{23}$

These are three of twenty-four verses beginning the second chapter of William Blake's prophetic poem "Jerusalem." They suggest that state power rests upon a blood sacrifice, an 18th century anthropological view. They suggest a mythological history of Albion and the Druids. These were not themes of the book. Nor, if we put the verses in their context - they are preceded by lines of innocent, pastoral forgiveness, they are followed by verses of "War \& howling" and direct references to the Napoleonic wars - are the essays of the volume concerned with Christian values towards capital punishment or the wars and militarism of the 18th century. If we would not accept some undertones in "Jerusalem," otherwise the poem raised at an epistemological level a theme we accepted in historical practice: viz., the distrust of the "generalizing Demonstrations of the Rational Power," and reliance upon the "Minute Particulars." This contrast parallels One and All.

stresses the saturnalia rather than the apocalypse of Tyburn.

22 I set out to show that they were part of work-discipline. See The London Hanged (1991).

23 No.3 (Winter 1957-1958). 
Whigs and Hunters, the comparison volume to Albion's Fatal Tree, seems to support the supposition that it is hanging, or the Death of One, that preoccupies the history books. This support is weak at the knees. The passage of the Waltham Black Act of 1723 suggests "some complicity between the ascendancy of the Hanoverian Whigs and the ascendancy of the gallows." This thesis uses the term "gallows" in two different ways parallel to the two meanings he gives to the word "law," viz., namely as legal statute and as actual fact. In an earlier treatment Sir Leon Radzinowicz observed that the Act constituted "a complete and extremely severe criminal code." ${ }^{24}$ Legal algebra is required to enumerate accurately its capital offences; it clearly has 50, but a finer calculation puts the total between 200 and 250, and Arthur Koestler even got 300 . While a lot of fear was created, few hanged, and far from heroically: forty were arrested for the murder of a forest keeper and three hanged in Hampshire - they couldn't speak or stand at the gallows. At Tyburn seven Waltham Blacks were executed - some too sick to stand in the cart, another kept wishing for a reprieve. Only at Winchester did the prisoners "appear to be a dangerous set of rogues determined ... to rescue themselves in defyance of $\&$ in opposition to all manner of law and justice." ${ }^{25}$ Although these people came from communities struggling to retain their common rights against Whigs, the placemen, the contractors and new moneyed men, they are not heroes by any stretch. The hangings are pathetic. Nor do they hold Thompson's interest. Whereas for Radzinowicz the episode gave rise to reflections on hanging, for Thompson the occasion gives rise to reflections about law. The Waltham Black Act was not an efficient hanging apparatus: but on the books it was terrible.

So, while it is true that hanging appears in most all the history books, it would be misleading to say that any of them are about capital punishment as such. Even when it is most evident, as rhetoric and deed, as in The Making, a close examination reveals a surprising treatment, individually heroic, politically defeated. Thus, our third supposition must be qualified.

Our final supposition is that hanging or capital punishment does not much appear in Thompson's political writing. It does not appear at all in "Exterminism." Nor in Protest and Survive. I have not found it in Writing By Candlelight nor do I find it in The Heavy Dancers, but I must say that I have not culled them carefully and traces might be evident in figures of speech, or incidental remarks. Certainly, though, in more than two dozen essays, capital punishment is not the subject or theme. This is not to say that the problem of One and All is absent; it is very much present in Protest and Survive where it appears in the Blake sense ("Labour well the Minute Particulars, attend to the Little-ones"). Thompson quotes from the book, Living Beneath the Atomic Cloud, about the children survivors at Nagasaki. Michiko Ogino, age ten, said, "Mamma was bombed at noon when getting eggplants in the field." She rescued her two-year-old child, and then died that night. Thompson then turns to the strategic discussion by Conservative MPs who show that "effective measures might reduce 
deaths in a nuclear war in this country from about thirty-five millions to just twenty millions" and Thompson says "I will allow that fifteen millions in savings is a substantial number indeed." 26

These on the whole are late essays. If we look at the earlier essays, particularly in The New Reasoner, our supposition becomes less tenable. There are several references and allusions to capital punishment. Imre Nagy is executed by the Soviets. He had released imprisoned Communists. He was accused of not having executed any of the young freedom-fighters. In some ways, his death is "the moment of truth" for the whole political project of The New Reasoner. There are other references: to Djanula Boulured, an Algerian woman, on death row, to Arthur Thistlewood, who is compared by a Cold Warrior to an "atom-bomb traitor." It had been brought up in the debate about socialist humanism initiated in the first issue of The New Reasoner. Harry Hanson's “Open Letter to Edward Thompson" begins with a statement of his own departure from the CP. "Looking back, I realise that it was the Rosenberg affair which brought up my long-accumulated nausea." "My realisation that their sufferings had been cynically exploited by politicians who cared nothing for them as individuals ...."27

What explains the frequency of such references in the politics of 1956 is simple. In August 1955 Arthur Koestler and Victor Gollancz formed the National Campaign for the Abolition of Capital Punishment in the wake of the hanging of Ruth Ellis who had murdered her abusive lover. By February 1956 the Campaign, led by Tory and Labour MPs and Christian Action, had 33000 members ${ }^{28}$ During four days in October 1955 Victor Gollancz wrote Capital Punishment: The Heart of the Matter. "Capital punishment is wrong, and that is all there is to it," he wrote. He began with the Biblical story of the woman taken in adultery, "He that is without sin among you, let him first cast a stone at her." He concluded quoting Dostoevsky's Idiot, an apt subject, less for the reason given, than for the fact that it was the dim-wits hanged in the post-war period, such as Derek Bentley and Evans, that mobilized the abolitionists to action, for the abolitionists were as selective of those they mentioned as victims of the death penalty as were the New Leftists. The abolitionists stressed the ignorant and retarded, the New Leftists stressed the revolutionary democrats. Only Arthur Koestler mentioned them all.

Meanwhile, during August and September 1955 Arthur Koestler wrote a draft of Reflections on Hanging which was serialized in The Observer in early 1956 before being published as a book in April. Kruschev was publishing Stalin's crimes, and Koestler those of the English. "Great Britain is that peculiar country in Europe where people drive on the left side of the road, measure in inches and yards, and hang people by the neck until dead." "Hanging has a kind of macabre cosiness, like a slightly off-colour family joke, which only foreigners, abolitionists, and other humourless creatures are unable to share." 29 "Executions are so much a part of British history

26 Protest and Survive, 31-4.

27 Harry Hanson, "An Open Letter to Edward Thompson," The New Reasoner, no.2 (Autumn 1957), 79. 
that it is almost impossible for many excellent people to think of the future without them," Viscount Templewood had written. As part of English chauvinism, nationalism, character, or peculiarities, he turned to history and to the "Bloody Code." In this work he was aided by Leon Radzinowicz.

Koestler and Gollancz closed their campaign not long after the House of Commons voted to abolish hanging. Many of the abolitionists went on to organize the CND and the first Aldermaston march in 1958. While Thompson was largely silent on the campaign of the abolitionists, he joined the anti-nuclear campaign wholeheartedly. CND became a defining moment for the New Left. Later Thompson referred to it as "the miracle of CND." ${ }^{30}$ Mervyn Jones wrote in The New Reasoner, "I am deeply convinced that the moral protest, the Aldermaston mood, is the mainspring of the campaign, as of all campaigns concerned with the right to life, whether the target has been the slave trade or capital punishment." The Death of One, like the Death of All, is presented as moral protest. The sub-text is that they were not class demands. A couple years later Thompson touched upon the subject, damning with faint praise. In "Outside the Whale," he remembered that after the war " ... important radical campaigns were fought (often on 'personal,' 'non-political,' causes, such as the abolition of capital punishment) within the margin of the general retreat. As we entered the fifties the retreat began to look like a rout."

I have said that Thompson was silent during the abolitionist campaign of 1956; he was fighting for his political life elsewhere. Yet I speculate that he was listening intently to the debate between the hangers and the abolitionists. The published evidence for this is in "The Open Letter to Leszek Kolakowski" (1973) which he called "a private meditation." It is signalled by isolation and posturing. He compares himself to an extinct bird, the bustard. He also compares himself to his worst fears, a nuclear explosion (referring to the Communist revisionism of 1956, "The intellectual particles produced in that moment of ideological fission have now fallen out over most parts of the political globe") as well as to a condemned man ("If this is so, there might, at an outside chance, be a stay of execution for the bustard after all"). Perhaps it is to such similes that we ought to apply his self-criticism ("I ought not to have reduced so general a case to such personal terms"), yet we may treat them, not as postures but as clues. He quoted for Kolakowski a poem he wrote in 1956 called "In Praise of Hangmen,"

How can we other than

Honour that man

Who undertakes this social trust

Since someone must?

How much more honour then

To all those dedicated men

Who saved society

29 Arthur Koestler, Reflections on Hanging (1956) which with C.H. Rolph's editing was republished as Hanged by the Neck: An Exposure of Capital Punishment in England, a Penguin Special (1960), and Iain Hamilton, Koestler: A Biography (New York, 1982).

30 "The Peculiarities of the English" in The Poverty of Theory, 76. 
By rope and calumny! So giving honour, we

Who moralise necessity,

With slats of sophistry erect

A gibbet of the intellect,

And from its foul and abstract rope

Suspend all social hope,

Until with swollen tongue

Morality herself is hung

In whose distended dedicated eyes

All honour dies.

Although Edward never burlesqued the subject, the irony of these lines is familiar: it provided the basis for Charles Duff's devastating send-up, A New Handbook on Hanging ("Dedicated Respectfully to The Hangmen of England and to similar constitutional Bulwarks everywhere") which was re-published as a paperback in the same year.

I think Thompson did not intervene directly in the debate about capital punishment because he was not an absolute abolitionist in the way of, for example, Victor Gollancz. Thompson was a soldier, not a pacifist.

To-day the deliberate increase in the chances of death,

The conscious acceptance of guilt in the necessary murder;

To-day the expending powers

On the flat ephemeral pamphlet and the boring meeting.

I believe he identified with this theme, from the first battles of the Second World War fought in Spain. The stanza is from W.H. Auden's Spain which Edward submits to moving explication in "Outside the Whale." Auden published the poem as a pamphlet in 1937. Three years later, after the Moscow trials, after Munich, after the Soviet-Nazi pact, after the collapse of the Popular Front, he re-published it having excised ("a calculated act of mutilation") two verses. These were the fulcrum verses in the structure of the poem, the ones that showed the possibility of "purposive historical commitment and of the redemption of man through political action."

... For the fears which made us respond

To the medicine ad. and the brochure of winter cruises

Have become invading battalions;

And our faces, the institute face, the chain-store, the ruin

Are projecting their greed as the firing squad and the bomb.

Madrid is the heart. Our moments of tenderness blossom

As the ambulance and the sandbag;

Our hours of friendship into a people's army.

I am not sure how to read these lines. Have our fears and our faces become hopeful, positive, thanks to Spain? Or, rather, thanks to our sacrifices in Spain, because Auden is commenting on the international brigades. Do we have to embrace the firing squad and the bomb, as necessary murders in the people's army? What does seem clear is that Auden, and his interpreter, place together the firing squad and the bomb, the Death of One and the Death of All.

We may sum up. We have surveyed Thompson's historical and political writing 
with a view to testing an hypothesis, that the former are concerned with hanging not war, and the latter with war not hanging. The history writing is concerned with the Death of One, the political writing with the Death of All. In examining the four suppositions comprising the hypothesis, we found all needed qualification. Two particularly may be repeated. First, the William Morris biography was concerned with martial virtues, and it was concerned with class war. Thus, it introduced a middle term between One and All. Second, the early political writing particularly mentioned some instances of capital punishment. In the past, Thompson found redemptive hope among some of those who were defeated; in the future he saw an apocalyptic end of civilization. In either case, his motivation was that purposive historical commitment through political action which he found wanting in Auden.

I said at the beginning that I was not sure what the hypothesis means, and I am still not. However wonderful as an expression of class solidarity the slogan 'One and All' may be, it has reached its limit as a tool of class analysis. We need middle terms. So instead, if we let (retaining the logical form):

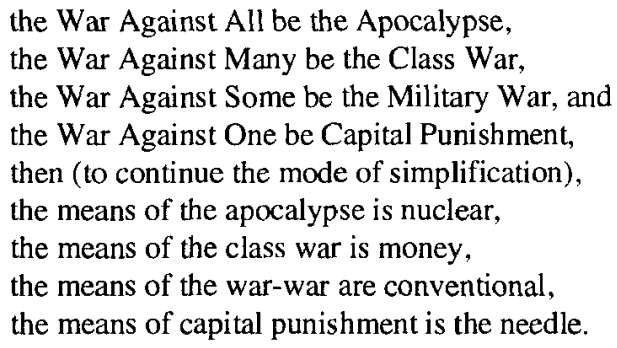

If this be granted, then we may look upon the dilemma Thompson expressed in another light. We see a continuum in these wars which permits the possibility of an apocalypse of one. In "The Poverty of Theory" he asked, "how does one do the symbolic rituals of Tyburn ... in terms of value, price, and profit?" This continuum suggests that the needle (or rope) is one of the determinants of the value of human - life. In Protest and Survive he wrote, "Deterrence has repressed the export of violence towards the opposing bloc, but in doing so the repressed power of the State has turned back upon its own author. The repressed violence has backed up, and has worked its way back into the economy, the polity, the ideology and the culture of the opposing powers. This is the deep structure of the Cold War." Is it not the deep structure of capital punishment as well?

4 October 1993 